Berkala Ilmu Perpustakaan dan Informasi, Vol. 15, No. 1, Juni 2019, Hal. 48 -59 DOI: 10.22146/bip.27506

ISSN 1693-7740 (Print), ISSN 2477-0361 (Online)

Tersedia online di https://jurnal.ugm.ac.id/bip

\title{
Pengaruh sosial media terhadap user engagement pada akun facebook perpustakaan perguruan tinggi
}

\author{
Nova Indah Wijayanti Rita Yulianti ${ }^{1}$ Bagus Wijaya ${ }^{1}$ \\ ${ }^{1}$ Perpustakaan Universitas Gadjah Mada \\ Bulaksumur PO Box 16 Yogyakarta \\ e-mail:nova_indah@ugm.ac.id
}

Naskah diterima: 15 Agustus 2017, direvisi: 15 April 2019, disetujui: 03 Mei 2019

\begin{abstract}
ABSTRAK
Pendahuluan. Penelitian ini bertujuan untuk mengetahui pemanfaatan sosial media khususnya Facebook di perpustakaan khususnya mengetahui pengaruh konten akun facebook terhadap aktivitas pemustaka dengan level user engagement. Penelitian ini penting, karena sosial media belum dimanfaatkan secara optimal oleh perpustakaan

Metode penelitian. Penelitian ini merupakan penelitian deskriptif dengan metode kualitatif. Pengumpulan data dengan wawancara dan data historis akun Facebook yang diteliti dengan parameter user engagement yang meliputi 4 katageri yaitu (1) Literature Exhibits (2) Engaging topic (3) Community Building (4) Library showcasing. Pengumpulan data dilakukan dengan mengelompokkan data kategori user engagemet, dipilih yang paling banyak mendapatkan respon darifollower baik berupa like, share, atau comment dari masing-masing akun Data Analisis. Analisis data menggunakan content analysis, yaitu analisis terhadap isi posting yang mengandung kata yang telah ditetapkan dalam user engagement

Hasil penelitian. Akun Perpustakaan paling banyak memposting kategori Library showcasing, sedangkan user paling banyak merespon posting kategori Enganging topic. Facebook memiliki pengaruh meningkatkan user engagement tetapi tidak signifikan karena terdapat ketidaksesuaian antara posting admin dengan respon followers.

Kesimpulan. Fungsi sosial media di perpustakaan adalah sebagai saluran komunikasi, promosi, marketing, dan meningkatkan user engagement. Fungsi pengambilan keputusan secara cepat dengan memanfaatkan sosial media belum dilakukan
\end{abstract}

Kata kunci: user engagement; perpustakaan; facebook; sosial media; pemustaka

\section{ABSTRACT}

Introduction. This research aims to determine the utilization of social media, especially Facebook in academic libraries. It explores the impact of Facebook content to user activity with the level of user engagement. This research is considered signifincat due to the fact that social media has not been used optimally by the libraries.

Data collection methods. This research used a qualitative approach method with interviews by considering user engagement parameters in 4 categories: (1) Literature Exhibits (2) Engaging topic (3) Community Building (4) Library showcasing. This study also used data histories and Facebook content. Using 5 state academic libraries, the data was gatheres by grouping the data of the user engagement with the followers' response including activities of like, comment, shares from each account.

Analysis Data. This research was analysed by using a content analysis.

Results and discusions. Most libarires post the category of Library Showcasing, while most users respond to the category Enganging Topics. Facebook has effects of increasing user engagement. It is found that there is a mismatch between postings from admin staff and the follower responses. 
Conclusions. Social media function in library is considered as an effective channel of communication, promotion, marketing as well as to improve user engagement. The decicion making related to library services by utilizing social media has not been conducted.

Keywords: user engagement; library; facebook; social media; user

\section{A. PENDAhUluan}

Kultur perilaku pencarian informasi di internet terdapat dua hal yaitu search \& social (Rossmann et al. 2015). Artinya, pencari informasi mencari informasi yang dibutuhkan melalui search engine dan membaginya melalui sosial media. Sosial media memiliki sebuah fitur yang bisa memfasilitasi penggunanya untuk saling berbagi dan mendistribusikan informasi dalam komunitas online, misalnya dengan Facebook group dan Facebook fanpage. Komunitas online terbentuk karena kesamaan minat, hobi dan ketertarikan, misalnya hobi dengan $\mathrm{brand} /$ merk tertentu. Hal ini mendorong sebuah perusahaan untuk mengembangkan strategi baru membangun loyalitas (engagement) dengan pelanggan melalui sosial media. Selain itu pemanfaatan sosial media berkembang menjadi media kampanye atau branding perusahaan, produk dan perorangan atau public figure. Sesuai gambaran tersebut, maka bisa dikatakan sosial media memiliki kekuatan untuk membangun persepsi penggunanya apabila dimanfaatkan secara optimal.

Penggunaan sosial media telah membentuk dan mendukung cara baru dalam berkomunikasi, berinteraksi dan berkolaborasi. Sosial media memiliki keunggulan dalam efektifitas dan kecepatan penyampaian pesan. Sehingga teknologi sosial media berkembang pesat dengan adanya fasilitas untuk saling berbagi dan distribusi informasi dalam komunitas online, misalnya dengan Facebook group dan Facebook fanpage. Komunitas online terbentuk karena kesamaan minat, hobi dan ketertarikan, misalnya hobi dengan brand/merk tertentu. Sesama anggota saling berbagi informasi dan antusiasme mereka terhadap merek tersebut, sehingga lambat akan menimbulkan loyalitas. Hal ini menjadi mendorong sebuah perusahaan untuk mengembangkan strategi baru membangun loyalitas (engagement) dengan pelanggan melalui sosial media. Sehingga, beberapa perusahaan membuat komunitas brand mereka dalam sebuah Facebook fanpage yang berisi iklan, promosi dan komunikasi kepada pelanggan.

Efektivitas sosial media dalam membangun interaksi dengan masyarakat, telah diakui oleh pemerintah dengan memanfaatkan sosial media sebagai media hubungan masyarakat. Sosial media efektif dalam membangun hubungan antar individu atau antar institusi sebagai sarana penyebaran informasi publik. Sehingga lembaga pemerintah atau institusi banyak yang menggunakan sosial media sebagai salah satu saluran komunikasinya, salah satunya yaitu institusi perpustakaan. Permasalahannya adalah sosial media belum dimanfaatkan secara optimal oleh perpustakaan. Fungsi media sosial di perpustakaan lebih banyak untuk promosi, informasi kegiatan dan koleksi di perpustakaan, bahkan menduplikasi dari website perpustakaan (Rossmann et al. 2015). Hal ini terjadi karena ada jarak antara perpustakaan dengan user. Untuk itulah diperlukan konsep melibatkan user dengan user engagement. Engagement adalah keterlibatan secara multidimensi dalam berbagai kegiatan akademik (misalnya kehadiran, usaha, partisipasi dan perilaku). Engagement bisa dibangun dengan berbagai cara salah satunya dengan memanfaatkan teknologi informasi yakni web 4.0 untuk mendorong user aktif dan berinteraksi dengan user lainnya dan dengan perpustakaan sehingga terjadi kolaborasi untuk membangun komunitas perpustakaan.

Untuk itulah perpustakaan perlu mengeksplorasi pemanfaatan sosial media lebih dalam, karena fungsi dari sosial media bukan hanya pada taraf pemasaran tetapi dengan terjalinnya komunikasi dengan user. Hal ini perlu di buktikan di lapangan, fakta-fakta tentang sosial media di perpustakaan. Sosial 
media yang dipilih seperti facebook sesuai dengan data survei dari APJII yang menemukan fakta bahwa media sosial yang paling sering digunakan yakni facebook. (APJII 2016) Facebook juga sangat powerfull untuk bisa membangun user engagement asal bisa memaksimalkan fitur-fitur yang dimiliki (King 2015). Untuk itu diperlukan penguasaan dan eksplorasi terhadap fitur-fitur facebook dan optimasi melalui isi (content) yang di posting.

Penelitian ini bertujuan untuk mengetahui fungsi dan manfaat sosial media di perpustakaan, mengetahui pengaruh sosial media dengan tingkat keaktifan pemustaka, mengetahui peran sosial media dalam membangun user engagement. Hasil dari penelitian ini diharapkan memberikan manfaat menambah wawasan pengetahuan mengenai pemanfaatan teknologi informasi khususnya sosial media untuk mencapai visi dan misi perpustakaan, dan untuk mengoptimalkan sosial media demi mendukung terciptanya user engagement dengan pemustaka.

Berdasarkan latar belakang di atas, penelitian tentang user engagement facebook untuk akun perpustakaan sangat diperlukan, karena eksplorasi facebook bisa digunakan untuk saluran komunikasi yang efektif kepada pemustaka dan membangun brand perpustakaan secara komprehensif. Selain itu pada penelitianpenelitian sebelumnya belum diteliti hubungan antara user engagement dengan content facebook untuk akun perpustakaan, penelitian lebih banyak untuk membangun brand perusahaan seperti penelitian oleh Zheng dkk (Zheng et al. 2015). Kebaruan pada penelitian ini menggunakan metode wawancara mendalam terhadap user facebook, sehingga mendapatkan gambaran secara utuh pengaruh sosial media terhadap loyalitas pemustaka.

\section{B. TINJAUAN PUSTAKA Penelitian Terdahulu}

Penelitian terdahulu terkait pemanfaatan sosial media untuk meningkatkan user engagement terdapat tiga penelitian yang kami temukan. Ashley Krenelka Chase (Chase 2014) meneliti tentang teknologi yang digunakan untuk meningkatkan user engagement di perpustakaan. Penelitian dari Chase ini termasuk penelitian tindakan (action research) yaitu adanya kolaborasi atau partisipasi peneliti dengan sasaran penelitian. Salah satu strategi yang digunakan yaitu dengan memasang google maps untuk memfasilitasi user mengakses sumber-sumber informasi di perpustakaan secara rinci indoor map ruang-ruang di perpustakaan. Penelitian kedua adalah Hangbo Zou et. al. (Zou, 2015) meneliti tentang penerapan strategi user engagement di perpustakaan dengan analisis Twitter. Metode yang digunakan dengan menggunakan topic modelling dengan parameter user engagement. Penelitian ketiga Zheng dkk (Zheng et al. 2015), yang meneliti tentang konsep user engagement dalam kontek komunitas facebook. Metode penelitian yang digunakan berupa studi empirik berdasarkan survei online terhadap user. Penelitian ini merupakan penelitian lanjutan dari Zheng dkk. namun metode yang digunakan adalah kualitatif dengan menggunakan parameter user engagement yang diteliti oleh Hangbo Zou dkk. Tujuan penelitian ini untuk mengetahui tentang fungsi sosial media dan peran sosial media untuk membangun user engagement di perpustakaan melalui akun facebook perpustakaan.

\section{Library 4.0}

Konsep Library 4.0 merupakan pengembangan dari web 4.0. Pengembangan Library 4.0 meliputi fokus pada pemanfaatan teknologi digital dan internet di perpustakaan yang terhubung dengan komunitas sosial dengan memperhatikan aspek ramah lingkungan seperti makerspace, google glass, augmented reality, big data dan cloud computing (Noh, 2015).

Syarat untuk membangun web 4.0 adalah ubiquity, identity \& connection, yaitu makna antara online dan offline menjadi kabur, pengguna terhubung dengan web 4.0 kapan saja dan dimana saja. Identity artinya akan ada protokol khusus yang mengidentifikasi siapa user, kebutuhan user dan apa yang mereka lakukan. Connection artinya jaringan yang terus terhubung. Kelebihan dari konsep ini adalah informasi yang diberikan ke pengguna lebih 
efisien dan sesuai kebutuhan dengan meminimalisir informasi spam/sampah karena sudah tersaring melalui protocol khusus.

\section{Layanan Perpustakaan}

Layanan perpustakaan berupa penyediaan bahan pustaka atau sumber-sumber informasi yang sesuai dengan kebutuhan pemustaka. Secara teknis layanan terdiri dari 3 (tiga macam) yaitu: Layanan pemakai, yaitu layanan yang langsung berhubungan dengan pemustaka, misalnya layanan sirkulasi, referensi, OPAC, internet, wifi, multimedia. Layanan teknis, yaitu layanan yang menunjang ketersediaan fasilitas dan sumber-sumber informasi di perpustakaan seperti pengembangan koleksi, pengadaan bahan pustaka dan pengolahan. Layanan administrasi, yaitu layanan yang berhubungan dengan pemustaka dan bersifat administratif (surat menyurat dan dokumentasi) seperti pembuatan kartu anggota, pembuatan surat bebas pustaka, surat tagihan denda dan lain-lain.

\section{Facebook}

Ada dua hal berbeda terkait konsep sosial media, pertama teknologi yang digunakan, yang kedua layanan yang ditawarkan oleh platform sosial media yang digunakan (Obar and Wildman 2015). Sosial Media disarikan dari pendapat Obar dan Wildman adalah sebuah media online, dengan para penggunanya bisa dengan mudah berpartisipasi, berbagi dan menciptakan isi, meliputi blog, jejaring sosial, wiki forum dan dunia virtual. Jadi secara singkat media sosial adalah media yang isinya (content) dibuat dan disalurkan melalui interaksi sosial tanpa dibatasi oleh ruang dan waktu. Disebut ada interaksi sosial karena dalam komunikasinya bersifat dua arah, bahkan bisa dalam satu grup memberikan respon. Platform media sosial berkembang seperti bisa menampilkan profil, kirim komentar, membentuk pertemanan (grup) dan pesan pribadi (private message). Contoh media sosial yang populer adalah Facebook, Twitter, LinkedIn, Google+, Instagram, Pinterest dan lain-lain.
Dunia bisnis baik skala kecil maupun besar telah memanfaatkan facebook untuk menjalin relasi, pemasaran dan pendekatan kepada pelanggan dengan cara membangun meningkatkan engagement di fanpage perusahaan. Adopsi manfaat facebook dari bisnis bisa dimanfaatkan oleh perpustakaan untuk meningkatkan layanan pengguna. Facebook merupakan sarana untuk menjangkau pengguna lebih luas dan sebagai sarana pemasaran yang gratis. Hal ini yang mendasari institusi perpustakaan untuk pemasaran yang efektif dan penyebarluasan informasi yang efisien (Ofili \& Emwanta, 2014). Eksplorasi manfaat fanpage Facebook untuk organisasi/perusahaan sebagai berikut (Dasilva, 2013): 1. Mampu meningkatkan hubungan antara perusahaan dengan individu/konsumen/ user. Dengan sosial media terjadi komunikasi yang interaktif dan dua arah, sehingga mampu mendekatkan pada user. 2. Mampu mempercepat proses pembuatan keputusan Hal ini bisa dilakukan dengan memposting sebuah topik dalam bentuk survei dan meminta user untuk memberikan pendapatnya. Platform Twitter sudah tersedia fiturnya, sedangkan untuk Facebook bisa dihitung dari komentar yang masuk. 3. Meningkatkan brand awareness dan user engagement. Sosial media mempunya fitur untuk bisa sebagai wadah komunitaskomunitas, sehingga memudahkan bagi perusahaan/organisasi untuk melakukan kegiatan promosi dan berinteraksi dengan user. User memiliki saluran untuk memberikan pendapatnya pada organisasi/perusahaan, sehingga bisa meningkatkan engagement pada perusahaan/organisasi. Fitur ini di Facebook fitur ini terdapat dalam Facebook fanpage. 4. Memudahkan marketing/promosi, sosial media dapat dimanfaatkan untuk pemasaran dengan jangkauan yang lebih luas. Konten yang menggugah follower untuk merespon baik share, comment atau like bisa berpotensi menjadi viral dengan ini menghemat biaya untuk promosi, yang tadinya dengan menggunakan brosur yang dibagi-bagikan kepada khalayak, dengan sosial media cukup dilakukan pada akun yang dimiliki. 
Beraneka macam platform sosial media, tentunya memiliki karakteristik yang berbedabeda, sehingga user bisa memanfaatkan sesuai dengan keperluannya. Data APJII tentang pemanfaatan sosial media terlihat dalam Gambar 1.

Facebook memiliki fitur layanan untuk berbagai macam tipe akun sesuai dengan fungsinya masing-masing. Tipe akun dalam facebook sebagai berikut: 1. Akun Personal, akun personal di Facebook adalah akun berisi data pribadi untuk berinteraksi secara santai dan menjalin komunikasi dengan friend list (daftar pertemanan) yang dimiliki. Menambah pertemanan bisa dengan mengundang melalui nama akun dan email pemilik akun. Batas pertemanan di akun personal sebesar 5.000 orang (friend) setelah mencapai batas itu tidak bisa menambah pertemanan lagi. 2. Fanpage Facebook, adalah fasilitas yang disediakan oleh facebook yang berfungsi seperti blog yang berisi informasi sesuai dengan keinginan pemilik akun. Tujuannya memberikan informasi secara terbuka kepada publik. Biasa digunakan oleh pebisnis online, public figure seperti tokoh terkenal, pejabat dan artis, digunakan untuk institusi perusahaan dan lain-lain. Tidak ada batas pertemanan di akun fanpage, pertemanan bentuknya fan (penggemar) atau follower yang bisa bertambah sebanyak-banyaknya. Untuk konten difanpage yang bisa posting yakniadmin fanpage, follower tidak bisa posting konten hanya bisa comment, share dan like. 3. Group, Facebook group adalah ruang untuk berkumpulnya kelompok atau komunitas dengan minat yang sama biasanya untuk berdiskusi dengan topik tertentu. Ciri dari facebook group adalah: pemilik/admin diperlihatkan, status hubungan di group adalah member atau anggota dan setiap member bisa mengisi konten di post item.

\section{User Engagement}

Konsep engagement menjadi salah satu faktor kunci keberhasilan, dalam hal ini adalah keberhasilan mahasiswa. Artinya, mahasiswa terlibat aktif dalam kegiatan dan hal-hal yang dapat mempengaruhi keberhasilan studi. Engagement adalah keterlibatan secara multidimensi dalam kegiatan akademik (misalnya kehadiran, usaha, partisipasi dan perilaku). Engagement bisa dibangun dengan berbagai cara salah satunya dengan memanfaatkan teknologi informasi melalui web 2.0 untuk mendorong $u$ ser aktif dan berinteraksi dengan user lainnya dan dengan perpustakaan sehingga terjadi kolaborasi untuk membangun komunitas perpustakaan (Richar, 2013). User engagement meliputi reaksi awal user terhadap teknologi, kemudian berkelanjutan dengan sistem informasi dari waktu ke waktu. Menurut Heater O' Brien (2014) user engagement merupakan suatu metode untuk mengevaluasi pencarian (search), jejaring sosial, dan aplikasi hiburan. Dengan kata lain, user engagement adalah merupakan asesmen pada individu berkaitan responnya terhadap beberapa tawaran, produk dan pelayanan. Dalam konteks internet respon berupa klik link, comment, view video, share dan download.

Konsep user engagement ada 4 kategori yaitu (Zou, 2015): 1. Literatur exhibits, secara harfiah diartikan sebagai pameran literatur. Artinya perpustakaan memamerkan/ menginformasikan berbagai koleksi perpustakaan seperti voucher buku baru, video terbaru, list jurnal terbaru dan berbagai dokumen yang dapat ditemukan secara online. 2. Engaging topic, pustakawan memposting konten yang menarik user, sehingga mengundang user untuk merespon seperti like, comment dan share. 3. Community building, artinya membangun komunitas, yaitu pustakawan berinteraksi dengan user melalui akun sosial media dan membentuk virtual community seperti facebook group atau chat group. 4. Library showcasing, maksudnya perpustakaan menginformasikan atau menampilkan informasi terbaru tentang kegiatan, program-program maupun berita perpustakaan.

\section{Saluran Komunikasi}

Kemajuan teknologi informasi membawa dampak terciptanya saluran media baru yang disebut sebagai sosial media tempat distribusi dan penyebaran informasi melalui interaksi sosial. Sesuai dengan kultur perilaku pencarian 
informasi di internet terdapat dua hal yaitu search \& social (Rossmann et al. 2015). Sifat informasi menjadi dua arah karena adanya interaksi sosial ini. Dalam proses informasi terdapat keterlibatan audien sehingga tercipta adanya komunikasi interaktif dan meningkatnya fleksibilitas menentukan bentuk dan konten pesan. Hal ini mendorong terciptanya bentukbentuk informasi yang semula hanya teks, kemudian dilengkapi dengan gambar/visual dan video (audio visual) dengan tujuan memperluas target audien.

\section{METODE PENELITIAN}

Penelitian ini merupakan penelitian deskriptif dengan metode kualitatif. Sampel dari penelitian ini akun facebook Perpustakaan pada Perguruan Tinggi dengan status PTN BH dengan periode penelitian Mei hingga Juni 2017. Tujuan dari penelitian ini mendapatkan deskripsi data mengenai jenis posting facebook yang mempengaruhi user engagement. Penelitian dengan observasi, wawancara dan mengumpulkan data historis dari posting di akun facebook Perpustakaan Perguruan Tinggi BHMN. Dari observasi awal, dipilih 5 akun facebook perpustakaan untuk diteliti yaitu: Perpustakaan Institut Teknologi Sepuluh November, Perpustakaan Universitas Diponegoro, Perpustakaan Universitas Airlangga, Perpustakaan Universitas Indonesia dan Perpustakaan Universitas Gadjah Mada. Pengumpulan data dari penelitian ini seluruh post dari akun facebook perpustakaan Perguruan Tinggi BHMN yang di posting mulai bulan Mei 2017 hingga Juni 2017. Pengambilan data dilakukan pada hari dan jam kerja yaitu Senin Jumat dari jam 07.00 - 16.00 WIB. Seluruh data dicatat dan diamati, termasuk respon dari follower baik berupa like, komentar maupun share, dalam bentuk tabel untuk dikelompokkan menjadi 4 kategori user engagement. dan dilengkapi dengan wawancara dengan follower dan admin akun facebook. Penelusuran data online berupa konten posting dan respon follower dari 4 tipe yaitu: 1. Identification, Identifikasi semua post termasuk individual post dari follower maupun staf perpustakaan, 2. Content, tekstual konten dari post, 3. Category fitur yang menggolongkan post, 4. Performance, matrik untuk mengukur pengaruh post (total like, comment dan share).

Kriteria akun yang ditetapkan untuk diteliti berupa akun yang aktif posting dalam kurun waktu Mei hingga Juni 2017. Setelah diadakan observasi akun yang aktif posting dalam kurun waktu tersebut adalah akun facebook Perpustakaan ITS, Perpustakaan UNAIR dan Perpustakaan Universitas Gadjah Mada, untuk itu dipilih 3 (tiga) akun tersebut yang diteliti. Unsur-unsur pada posting dari akun perpustakaan dikategorikan dalam tipe post user engagement yang meliputi 4 hal yaitu: Literature exhibits, Engaging topic, Community Building dan Library Showcasin. Tahapan dalam penelitian ini yakni: Unitilizing (pengunitan) yang meliputi: Sampling (penyamplingan), Recording/coding (perekaman dan pemberian kode), Reducing (penyederhanaan data), Inferring (pengambilan kesimpulan) Narating (penarasian).

Masing-masing dari 4 kategori ini dijabarkan istilah-istilah yang akan dianalisis pada Tabel 1.

Untuk menjelaskan teknik pengumpulan data, dari Tabel 1 tipe data tersebut divisualisasikan dalam bentuk diagram pada Gambar 2.

Dalam penelitian ini, mengamati situasi sosial yang terdiri dari 3 (tiga) elemen yaitu: 1 . Tempat penelitian, penelitian ini dilakukan secara online, 2. Pelaku, pelaku (aktor) yang diteliti follower akun facebook berupa respon mereka terhadap posting akun facebook, dan admin akun berupa jenis posting, 3. Aktivitas interaksi respon follower terhadap posting akun facebook. Sampel untuk penelitian ini menggunakan teknik purposive sampling, yaitu pengambilan data dengan pertimbangan tertentu untuk menggali informasi dari rancangan dan teori yang muncul(Moleong 2016).

\section{HASIL DAN PEMBAHASAN}

Penelitian ini dilakukan pada bulan MeiJuni 2017, pendekatan yang akan dipakai adalah pendekatan kualitatif, peneliti bertindak selaku instrument itu sendiri. Analisis yang dilakukan bukan hanya menghitung kata-kata atau 
penggalian konten objektif dari teks melainkan untuk memeriksa makna, tema dan pola dalam teks tertentu. Hal ini memungkinkan peneliti untuk memahami realitas sosial secara subjektif tapi ilmiah.

Tahap awal untuk mengetahui Akun facebook yang valid adalah dengan mencari informasi dari website resmi institusi perpustakaan tersebut. Website institusi mencantumkan link ke akun facebook sehingga dapat ditelusur akun facebook yang valid. Setelah diadakan penelitian, dari rancangan awal 5 akun facebook perpustakaan, hanya 3 yang aktif posting. Untuk itu penelitian difokuskan pada 3 akun facebook aktif yaitu: Perpustakaan ITS, UNAIR Library University dan Perpustakaan Universitas Gadjah Mada. Hasil penelitian terhadap aktivitas posting dan respon follower selama kurun waktu penelitian, dapat dilihat pada Tabel 2.

Pengumpulan data dilakukan dengan mengelompokkan data kategori user engagement. Sesuai dengan tujuan dari penelitian ini yaitu mengetahui pengaruh konten facebook perpustakaan terhadap user engagement, maka posting konten yang dianalisis dan dipilih yang paling banyak mendapatkan respon dari follower baik berupa like, share, atau comment dari masing-masing akun. Hasil penelitian menunjukkan data seperti yang terlihat pada Tabel 3 .

Adapun Profil dari ketiga akun tersebut adalah sebagai berikut:

\section{- Akun Perpustakaan ITS}

Gambar yang ditampilkan di profil berupa logo Perpustakaan tersebut. Di halaman profil juga dicantumkan nomor kontak dan nomor dan link ke website yang dimiliki. Tipe akun berupa fanpage jadi follower bisa bertambah sebanyak-banyaknya. Melihat dari halaman profil ini, akun ini yang berfungsi sebagai sarana komunikasi dengan usernya. Di halaman profil juga tercatat pesan yang masuk ke admin dibalas kurang dari 1 (satu) jam. Hal ini menunjukkan bahwa admin cukup aktif dalam memberikan respon kepada user yang bertanya melalui chat atau mengirimkan pesan ke admin. Merujuk dari halaman profil ini, akun ini sudah memanfaatkan sosial media sebagai saluran komunikasi di Perpustakaan. Informasi tentang link koleksi digital dan link ke akun sosial media lain (instagram) yang dimiliki juga dicantumkan pada data profil (about). Fungsi sosial media terutama facebook yang dikelola akun ini juga kami dapatkan informasinya dari hasil wawancara dengan admin yaitu akun ini sudah memanfaatkan fungsi sosial media sebagai ajang promosi dan marketing. Admin yang berfungsi mengelola dalam bentuk tim, namun belum terjadwal secara konsisten untuk posting di akunfacebook.

\section{- Akun UNAIR Library}

Gambar 3 menunjukkan profil yang ditampilkan berupa foto kegiatan perpustakaan di tahun 2017. Tampak di halaman profil berbagai kegiatan unggulan ditampilkan dalam satu frame. Hal ini menunjukkan akun UNAIR Library cukup efektif memberikan informasi kegiatan dalam satu kali klik. Halaman profil juga terdapat kontak person yang bisa dihubungi. Tipe akun ini fanpage. Untuk chat dibalas, keterangan yang di dapat di halaman profil adalah kurang dari beberapa menit, artinya pesan yang masuk cepat dibalas oleh admin. Data profil tersebut juga memuat informasi lokasi dari perpustakaan dengan memanfaatkan fitur google maps, jadi jika ada follower yang mencari lokasi bisa ditemukan dengan mudah. Follower yang memberikan review tentang akun perpustakaan ini sebanyak 41 orang dengan point total 4.1 Keterangan di halaman profil menyebutkan dengan jelas Education-Library, artinya akun ini merupakan fanpage tentang pendidikan khususnya perpustakaan. Penelusuran lebih lanjut tentang profil terlihat dalam gambar berikut ini: data profil (about) tersebut menunjukkan akun ini melengkapi informasi dengan jam pelayanan perpustakaan. Profil akun ini juga melengkapi informasi dengan memberikan link ke channel Youtube yang mereka miliki. Penelusuran kami terhadap channel Youtube yang dimiliki, admin cukup aktif memposting kegiatan perpustakaan. Akun ini memiliki admin khusus yang 
bertugas mengelola sosial media yang dimiliki. Informasi ini kami dapatkan dari hasil wawancara dengan admin akun. Informasi tentang fungsi sosial media bisa terlihat dari hasil wawancara tersebut yaitu facebook berfungsi sebagai sarana promosi dan marketing termasuk dalam kegiatan hubungan masyarakat (humas) dan dikelola oleh admin khusus sekaligus mengelola akun sosial media yang lain. Adapun informasi jadwal posting di facebook dapat kami peroleh dari hasil wawancara dengan admin. Informasi dari admin akun ini cukup aktif dalam melakukan aktivitas posting. Admin memiliki jadwal konsisten untuk posting dan update facebook setiap harinya.

- Akun Perpustakaan Universitas Gadjah Mada

Pada halaman profil menunjukkan tipe akun adalah personal bukan fanpage. Jumlah pertemanan saat ini adalah 2.223 orang. Tipe akun personal memiliki jumlah limit daftar pertemanan yaitu 5.000 sesuai dengan ketentuan dari facebook. Konsekuensinya ketika jumlah pertemanan sudah mencapai 5.000 orang maka akun tidak bisa menambah jumlah pertemanan. Pada halaman profil cover yang ditampilkan foto pemberian hadiah atau kenang-kenangan dari suatu kegiatan. Tidak ada keterangan di dalam foto yang menunjukkan waktu dan acara yang dilakukan.

Gambar dari data profil di halaman facebook akun ini untuk banner berupa kegiatan yang dilaksanakan perpustakaan, yaitu sebagai berikut: pada bagian introduction disebutkan nama institusi dan kota tempat institusi berada, tidak dilengkapi dengan nomor kontak dan email yang bisa dihubungi. Informasi dari admin posting belum terjadwal secara rutin, tetapi ada progres setiap bulannya. Akun ini memiliki admin khusus untuk mengelola, berjumlah 1 (satu orang). Adapun fungsi sosial media untuk mengambil keputusan. Ketiga akun yang kami teliti secara online, dari belum dilakukan posting tentang survei atau topik, membutuhkan respon jawaban dari user dalam kurun waktu dua bulan waktu penelitian.

\section{Peran Sosial Media terhadap Aktivitas Pemustaka}

User engagement meliputi reaksi awal user terhadap teknologi, kemudian berkelanjutan dengan sistem informasi dari waktu ke waktu. Menurut Heater O' Brien (2014) user engagement merupakan suatu metode untuk mengevaluasi pencarian (search), jejaring sosial, dan aplikasi hiburan. Data tentang aktivitas user karena mendapat informasi dari sosial media, kami peroleh dari hasil wawancara dengan follower. Akun Perpustakaan ITS menunjukkan bahwa perpustakaan cukup sering posting kegiatan yang diikuti oleh pemustaka. Jika dihubungkan dengan jawaban follower, maka terdapat kesesuaian karena kegiatan perpustakaan yang diposting admin mendapat respon yang cukup baik dari user. Akun UNAIR Library menunjukkan bahwa perpustakaan memiliki program yang melibatkan user yaitu pameran dan bursa buku bekas. Admin cukup sering mensosialisasikan kegiatan tersebut di akun facebook. Akun Perpustakaan Universitas Gadjah Mada sudah memanfaatkan fungsi sosial media untuk meningkatkan user engagement dan brand awareness dalam bentuk informasi acara dan kegiatan perpustakaan.

\section{Sosial Media menjadi Sarana untuk Membangun User Engagement}

Beberapa penelitian terdahulu menemukan fakta bahwa engagement terdiri dari aktivitas user, perilaku, tujuan, mental, kemampuan keterampilan motorik yang bermanifestasi menjadi perhatian, ketertarikan, keingintahuan dan motivasi (O'Brien 2008). Jadi pengalaman dan pengetahuan dari user mempengaruhi tingkat engagement mereka terhadap suatu hal. Dengan demikian yang dimaksud dengan engagement adalah sebuah konsep kerangka kerja yang secara holistik memahami integrasi antara user dan beberapa variabel dalam sistem sehingga bisa mempengaruhi user yang tadinya tidak terkesan menjadi terkesan dan terikat (engage). Merujuk pada definisi tersebut maka ada beberapa hal yang bisa digunakan untuk meningkatkan user engagement.

Upaya yang efektif untuk mengetahui cara meningkatkan user engagement adalah 
mengetahui optimasi sosial media. Penggunaan sosial media untuk meningkatkan user engagement sebagai berikut (King 2015): 1. Listening (Mendengarkan), hal ini dimungkinkan dengan memanfaatkan fitur di sosial media yang bisa disetel ada pemberitahuan (notifikasi) apabila akun perpustakaan disebut atau ditandai (tag) 2. Making connection (menghubungkan), Sosial media memiliki fasilitas untuk terhubung dengan user di mana saja, 3. Memperoleh respon, respon dari user terhadap suatu postingan di sosial media bisa dipancing melalui beberapa kalimat pertanyaan maupun pilihan, sehingga cepat diketahui minat dari user. 4. Dimudahkan dengan adanya perkembangan mobile technology. Aplikasi sosial media berkembang dengan cepat di mobile technology. Platform sosial media bisa diakses dari mana saja selama terkoneksi dengan jaringan internet dengan perangkat yang sangat ringan dan mudah yaitu smartphone. 5. Memperluas jangkauan user, keuntungan untuk perpustakaan bisa tetap menjangkau user di mana saja dan berkomunikasi secara interaktif.

Penelitian ini menunjukkan facebook memiliki pengaruh terhadap user engagement, yaitu sesuai data wawancara kami dengan beberapa narasumber bahwa mereka sering memberikan respon dan mengikuti kegiatan perpustakaan karena mendapat informasi di facebook. Tetapi jika dilihat dari perbandingan antara jumlah follower dengan respon dari suatu postingan, maka terdapat perbedaan yang signifikan, yaitu hanya sekitar $10 \%$ follower yang memberikan respon terhadap posting. Hasil penelitian ini, facebook memiliki pengaruh meningkatkan user engagement tetapi tidak signifikan.

Penelitian ini menunjukkan strategi yang banyak dipakai oleh perpustakaan kategori Library Showcasing yaitu perpustakaan banyak memposting kegiatan perpustakaan seperti even, pameran, workshop dan lain-lain berupa informasi searah. Sedangkan dari sisi user, respon terbanyak tentang engaging topic, ada ketidaksesuaian antara sisi perpustakaan dengan penerimaan follower. Hal ini mengindikasikan bahwa perpustakaan belum memanfaatkan facebook secara optimal. Beberapa fitur facebook seperti facebook insight belum dieksplorasi oleh admin. Fitur ini bermanfaat untuk mengetahui sejauh mana posting yang diupload menjangkau user, mengetahui demografi, geografi, perilaku user, manfaatnya admin bisa memilih posting yang bisa mempengaruhi user. Sehingga posting bisa efektif dan sesuai target.

Selain itu juga ada beberapa tool yang bisa dipakai untuk mengetahui performance facebook. Manfaatnya penggunaan tool tersebut adalah untuk menganalisis performa dan monitor kinerja facebook, sehingga tujuan yang ingin diperoleh bisa tercapai dengan cara yang efektif dan efisien. Beberapa tool untuk menganalisa dan monitor facebook ini sangat mudah digunakan yaitu input url facebook dan tool akan mengukur kinerjanya. Hasil yang didapatkan berupa data statistik. Hasil penelitian kami juga menunjukkan strategi agar sebuah posting menjadi viral belum banyak dieksplorasi, sehingga beberapa posting yang ada tidak mendapat respon yang diharapkan. Secara teoritis, sosial media bisa mendukung tercapainya visi dan misi sebuah institusi apabila dimanfaatkan secara maksimal. Sehingga saran dari penelitian ini perpustakaan perlu mengeksplorasi fitur-fitur dan tool yang bisa meningkatkan kinerja sosial media yang dimiliki.

\section{E. KESIMPULAN}

Berdasarkan hasil penelitian, maka dapat ditarik kesimpulan sosial media khususnya facebook memiliki pengaruh untuk meningkatkan user engagement di perpustakaan. Hal ini diperkuat dengan fakta bahwa akun facebook perpustakaan yang paling banyak posting informasi memiliki jumlah follower dan respon follower terbanyak. Akun Perpustakaan ITS menunjukkan bahwa perpustakaan cukup sering posting kegiatan yang diikuti oleh pemustaka. Jika dihubungkan dengan jawaban follower, maka terdapat kesesuaian karena kegiatan perpustakaan yang diposting admin mendapat respon yang cukup baik dari user. Akun UNAIR Library menunjukkan bahwa perpustakaan memiliki 
program yang melibatkan user yaitu pameran dan bursa buku bekas. Admin cukup sering mensosialisasikan kegiatan tersebut di akun facebook. Akun Perpustakaan Universitas Gadjah Mada sudah memanfaatkan fungsi sosial media untuk meningkatkan user engagement dan brand awareness dalam bentuk informasi acara dan kegiatan perpustakaan.

Salah satu caranya membuat jadwal rutin menginformasikan kegiatan dan tambahan koleksi melalui akunfacebook perpustakaan.

\section{DAFTAR PUSTAKA}

Dasilva, J.A.P., Arratibel, A.G., Aierdi, K.M., Galdospin, T.M., Castillo, I.M., Mardaras, L. I., Gonzales, M.M.R., Santamarina, D.R. (2013): Companies on facebook and twitter. current situation and communication strategies. Revista Latina de Comunicación Social, 68, 676-695. DOI: 10.4185/RLCS-2013-996en

APJII. (2016). Infografis penetrasi \& perilaku pengguna internet di Indonesia 2016. Diakses 13 Juli 2017 dari https://apjii.or.id/ content/read/39/264/Survei-InternetAPJII-2016

King, D.L. (2015). Why use social media?. Lybara Technology Report, 51 (1), 6-10. http://dx.doi.org/10.5860/1tr.51n1

Kurniasih, N. (2015). Optimalisasi penggunaan media sosial untuk perpustakaan. Prosiding Seminar Nasional Komunikasi, Informasi dan Perpustakaan di Era Global, Juni 2016. Diakses 21 Juni 2017 dari https://www.academia.edu/27643549/Opti malisasi_Penggunaan_Media_Sosial_untu k_Perpustakaan

Noh, $\bar{Y}$. (2015). Imagining library 4.0: creating model for future library. The Journal of Academic Librarianship. 41 (6), 396-397
O'Brien, H.L., \& Toms, E.G. (2008). What is user engagement? A conceptual framework for defining user engagement with technology. Journal of The American Society for Information on Science and Technology, 59 (6), 938. https://doi.org/ 10.1002/asi.20801

Obar, J.A., \& Steven S. W. (2015). Social media definition and the governance challenge: An introduction to the special issue. Telecommunication Policy39(9), 745-750. https://dx.doi.org/10.2139/ssrn.2647377

Rossmann, D., \& Young, Scott W.H. (2015). Social media optimization: making library content shareable and engaging. Library $\mathrm{Hi}$ Tech Iss Library Hi Tech, 33 (4), 526-44. http://dx.doi.org/10.1108/LHT-05-20150053

Zheng, X., Cheung, C., Lee, M.K.O., \& Liang, L. (2015). Building brand loyalty through user engagement in online brand communities in social networking sites. Information Technology and People, 28 (1), 90-106. https://doi.org/10.1108/ITP-082013-0144

Zou, H., Chen, H.M., \& Dey, S. (2015). Understanding library user engagement strategies through large-scale twitter analysis. IEEE First International Conference on Big Data Computing Service and Applications, 30 March - 2 April 2015, California, USA https://doi.org/ 10.1109/BigDataService.2015.31

Ofili, D.N. \& Emwanta, M.G. (2014). Facebook as an information service delivery tool: perspectives of library staff at the University of Benin, Nigeria. African Journal of Library, Archives \& Information Science, 24 (2), 195-202 


\section{DAFTAR GAMBAR}

\section{KONTEN MEDIA SOSIAL YANG SERING DI KUNUUNGI}

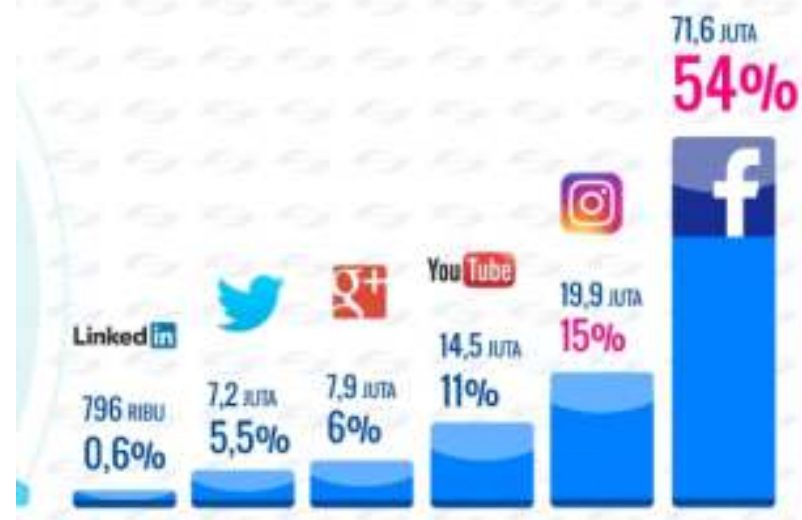

Gambar 1. Sosial Media yang Sering Dikunjungi Pengguna Internet (APJII, 2016)

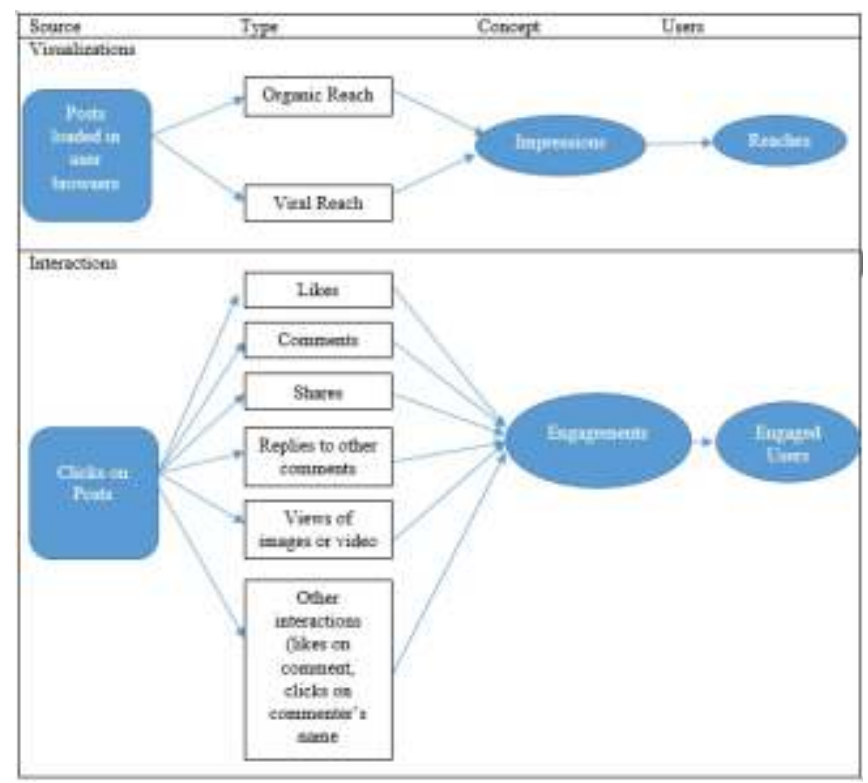

Gambar 2. Konsep Facebook Matrik

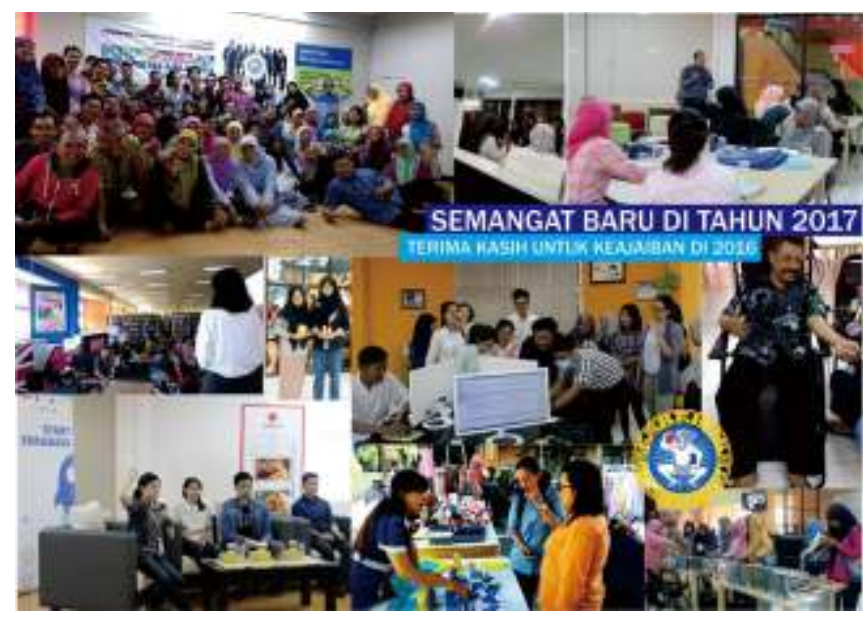

Gambar 3. Foto Profil Akun UNAIR Library 


\section{DAFTAR TABEL}

Tabel 1. Daftar Istilah User Engagement

\begin{tabular}{|c|c|c|c|c|c|c|c|}
\hline \multicolumn{2}{|c|}{ Literature Exibit } & \multicolumn{2}{|c|}{ Engaging Topic } & \multicolumn{2}{|c|}{ Community Building } & \multicolumn{2}{|c|}{ Library Showcasing } \\
\hline \multicolumn{2}{|c|}{ Archives } & \multicolumn{2}{|c|}{ Readinglist } & \multicolumn{2}{|c|}{ Join } & \multicolumn{2}{|c|}{ Public } \\
\hline \multicolumn{2}{|c|}{ Books } & \multicolumn{2}{|c|}{ School } & \multicolumn{2}{|c|}{ Celebration } & \multicolumn{2}{|c|}{ Librarian } \\
\hline \multicolumn{2}{|c|}{ List } & \multicolumn{2}{|c|}{ Excited } & \multicolumn{2}{|c|}{ Libraries } & \multicolumn{2}{|c|}{ Visit } \\
\hline \multicolumn{2}{|c|}{ Read } & \multicolumn{2}{|c|}{ Encourage } & \multicolumn{2}{|c|}{ Opening } & \multicolumn{2}{|c|}{ Staff } \\
\hline \multicolumn{2}{|c|}{ Bestselling } & \multicolumn{2}{|c|}{ Happu } & \multicolumn{2}{|c|}{ Program } & \multicolumn{2}{|c|}{ Branch } \\
\hline \multicolumn{2}{|c|}{ Articles } & \multicolumn{2}{|c|}{ Love } & \multicolumn{2}{|c|}{ Party } & \multicolumn{2}{|c|}{ Exibit } \\
\hline \multicolumn{2}{|c|}{ Cookbook } & \multicolumn{2}{|c|}{ Wisdom } & \multicolumn{2}{|c|}{ Creative } & \multicolumn{2}{|c|}{ Welcome } \\
\hline \multicolumn{2}{|c|}{ Benefit } & \multicolumn{2}{|c|}{ Enjoyed } & \multicolumn{2}{|c|}{ Story } & \multicolumn{2}{|c|}{ Opening } \\
\hline $\mathrm{Ph}$ & & Paren & & Quest & ons & & \\
\hline $\mathrm{Co}$ & & Favori & & Tod & & & ram \\
\hline Books & Reads & Readinglist & Encourage & Community & Join & Public & Staff \\
\hline List & Info & Excited & School & Party & Fun & Event & Exibit \\
\hline Read & Archives & Readeverywhere & Kidas & Art & Celebrate & Food & Opening \\
\hline Bestselling & Artivles & Learning & Parents & Family & Creative & Opening & Exibit \\
\hline Picture & News & Happy & Favorite & Summer & Club & Visit & Visit \\
\hline History & Photo & Wisdom & Blog & Program & Check & Event & Friends \\
\hline $\begin{array}{c}\text { Cookbook } \\
\text { Author }\end{array}$ & $\begin{array}{l}\text { Read } \\
\text { Check }\end{array}$ & Encourage & $\begin{array}{l}\text { Http } \\
\text { Show }\end{array}$ & $\begin{array}{l}\text { Opening } \\
\text { today }\end{array}$ & $\begin{array}{l}\text { Questions } \\
\text { story }\end{array}$ & $\begin{array}{l}\text { Library } \\
\text { Friday }\end{array}$ & $\begin{array}{c}\text { Park } \\
\text { Branch }\end{array}$ \\
\hline
\end{tabular}

Sumber: Zou (2015)

Tabel 2. Aktivitas Posting dan Respon Follower

\begin{tabular}{ccccc}
\hline Nama Akun & Jumlah Posting & Jumlah Like & Jumlah Share & Jumlah Komentar \\
\hline Perpustakaan ITS & 5 & 14 & 1 & 0 \\
UNAIR Library & 175 & 251 & 2 & 5 \\
Perpustakaan UGM & 16 & 106 & 0 & 2 \\
\hline
\end{tabular}

Sumber: data primer diolah (2017)

Tabel 3. Data Konten User Engagement Akun Facebook

\begin{tabular}{llcccc}
\hline No & Nama Akun & \multicolumn{3}{c}{ Kategori } \\
& & $\begin{array}{c}\text { Literature } \\
\text { Exibit }\end{array}$ & $\begin{array}{c}\text { Engaging } \\
\text { Topic }\end{array}$ & $\begin{array}{c}\text { Community } \\
\text { Building }\end{array}$ & $\begin{array}{c}\text { Library } \\
\text { Showcasing }\end{array}$ \\
\hline 1. & Perpustakaan ITS & 1 & 0 & 0 & 4 \\
2. & Unair Library & 2 & 11 & 24 & 138 \\
3. & Perpustakaan UGM & 1 & 2 & 1 & 12 \\
\hline
\end{tabular}

Sumber: data primer diolah (2017) 